\title{
NEWBORN BODY TEMPRATURE; COMPARATIVE STUDY TO SEE THE IMPACT ON NEWBORN BODY TEMPERATURE AFTER SKIN CONTACT OF MOTHER AND NEWBORN V/S CONVENTIONAL METHOD.
}

\section{M.S \\ Medical Officer \\ Aga Khan University Hospita Hyderabad, Sindh Pakistan. \\ 2. F.C.P.S, M.C.P.S \\ Senior Instructor Aga Khan University Hospita Hyderabad, Sindh Pakistan. \\ 3. M.S \\ Instructor \\ Aga Khan University Hospita Hyderabad, Sindh Pakistan. \\ 4. B.com, M.A (economics) Aga Khan University Hospital Hyderabad, Sindh Pakistan.}

Correspondence Address: Dr. Nigar Jabeen 32-C, Block-D Unit No. 6 Latifabad, Hyderabad Hyderabad, Sindh Pakistan. nigar.jabeen@aku.edu

Article received on: 19/12/2016

Accepted for publication: 15/02/2017

Received after proof reading: 06/04/2017

\section{Dr. Sadia Irum¹, Dr. Nigar Jabeen ${ }^{2}$, Dr. Raheela Baloch ${ }^{3}$, Ms. Kiran Mawani ${ }^{4}$}

ABSTRACT... Objectives... To identify comparative study to see the impact on newborn body temperature after skin contact of mother and newborn v/s conventional method. Study Design: Cross sectional, analytical study. Place and Duration: Department of Obstetrics and Gynecology (Unit-III) Liaquat University Hospital, Hyderabad Sindh from May 2013 to April 2014. Methods: All the laboring women with no any antenatal complication and with cephalic presentation admitted at term pregnancy for normal vaginal delivery along with new born with Apgar score more than 6 were approached by duty doctors. Written as well as verbal consent was obtained and women have allocated numbers, 1 to 120. The women were divided in two groups. Group A (baby warmer group 60 patients) and Group B (Skin to skin contact 60 patients). Results: 120 patients were recruited and randomly equally divided into two groups. There over all mean age of these patients was $26.7+-5.0$ years. In group $A$ the gravida was found as between 1 to 6 children in $60 \%(n=30)$, Compared with Group B, 64\% $(n=32)$. The overall mean hospital stay was as $6.6+\ldots 1.6$ hours. Personal health response like was found in $76 \%(n=38)$ patients with group A compared with Group B 86\% $(n=43)$. Mother response like was found in $76 \%(n=38$ patient in group A) compared with group B $76 \%(n=38)$. There is statically significant mean difference in $\mathrm{F}$ after one hour was observed $(P=0.001)$ between group $A$ and group $B$, no significant mean difference in temperature $\circ$ after 1 and 5 minutes were observed ( $P>0.05)$ compared with in group B $76 \%(n=38)$ patients. Conclusion: Skin to skin contact reduces the hypothermia, so it should be encourage and continue. Skin to skin contact is easy, cheap and helps in bonding of mother and baby. With this practice we will achieve the millennium development goal (MDG) that is to decrease neonatal mortality in Pakistan.

Key words: $\quad$ skin to skin contact, baby warmer, millennium development goal

Article Citation: Irum S, Jabeen N, Baloch R, Mawani K. Newborn body temprature; Comparative study to see the impact on newborn body temperature after skin contact of mother and newborn v/s conventional method. Professional Med J 2017;24(4):574-579. DOI: 10.17957/TPMJ/17.3748

\section{INTRODUCTION}

In developing countries around $21 \%$ infant mortality is caused by hypothermia. ${ }^{1}$ The temperature inside the womb and after the birth baby's temperature dropped rapidly due to rapid change in environmental condition. Delivered neonate loses heat in four different ways namely: evaporation, conduction radiation and conviction..$^{1,2}$

Thermal protection of the newborn remains a global concern and a challenge for health care providers despite advances in technology that provide warmth and minimize the risk of hypothermia after birth. ${ }^{3}$
However, main mechanism of loss of heat from newborn body is through evaporation of amniotic fluid and by conduction also, as a result neonates quickly depletes glucose stores, develop hypoglycemia, respiratory distress and metabolic acidosis as compensatory mechanism is prolonged, ${ }^{1,2,4}$ Therefore, efforts should be made to keep the neonate in natural thermal environment. This is achieved through quickly keeping the neonate on his mother's belly, swaddling him snugly and applying a head cap to prevent heat loss. ${ }^{5,6}$ Other ways to maintain the neonates temperature and to promote early bonding is to dry the neonate quickly then keep the neonate on mother's bare chest or abdomen 
and put a warm sheet over them till the delivery of placenta or episiotomy being repaired. , $^{5,6}$

Generally, loss of heat can exacerbates with surrounding air and a neonate can be hypothermic even at room temperature i.e. $30 \circ 0^{7,8}$ A neonate can predisposed to hypothermia from cold environment during first 10 to 15 minutes of their life and if we will not do necessary preventable measures for thermal protection then it can lead to fall in body temperature by 2-4 $\circ$. If such loss of heat due to conviction and radiation continued, then it will definitely lead to hypothermia. Commonest problem in new born till body is hypothermic and it accounts for a very high perinatal mortality. ${ }^{2}$

Cold stress can be harmful or even fatal. If increase the amount of oxygen and glucose needed so it is a duty of mother, labor and peads ward nursing staff to protect newborn from hypothermia related issues and its management. Therefore, this study is aimed to identify the various effects of thermo regulatory system of new born after skin to skin contact of mother and newborn.

\section{MATERIAL AND METHODS}

\section{Study Design}

Cross sectional analytical study

\section{Place and Duration}

Department of Obstetrics and Gynecology (UnitIII) Liaquat University Hospital, Hyderabad Sindh from May 2013 to April 2014.

\section{Sample Size}

120 women as per selected criteria were selected and distributed in equal half.

\section{Inclusion Criteria}

- Babies born with Apgar >6

- Primigravida and multigravida with no antenatal complications

- admitted at term for SVD

- Cephalic presentation

\section{Exclusion Criteria}

- Babies in distress, required instrumental or $\mathrm{C} /$ sec deliveries

- Mothers having medical disorders like diabetes, hypertension, APH

- Babies with congenital anomalies

- babies having Apgar <6

- Low birth weight babies

\section{Statistical Analysis}

Student $\mathrm{T}$ test applies for data entering by using SPSS version 16 .

\section{Procedure}

All laboring women as per selected criteria were approached by duty doctors. Written as well as verbal consent was obtained and women have the allocated numbers, 1 to 120 .

All the laboring women with no any antenatal complication admitted at term pregnancy with cephalic presentation for normal vaginal delivery along with new borns with Apgar score more than 6 were approached by duty doctors. Written as well as verbal consent was obtained and women have allocated numbers, 1 to 120 . The women were divided in two groups. Group A (baby warmer group) and Group B (Skin to skin contact). In group A (baby warmer) having allocation numbers 1 to 60 , in which baby was taken out to baby warmer, After Completion of group A, moved to group B (skin to skin contact) having allocation numbers from 61 to 120 , that have skin to skin contact, i.e by placing baby on mother bare chest or abdomen shortly after birth for five to ten minutes, while umbilical cord was cut and placenta was delivered and then recorded axillary temperature by placing the bulb of mercury thermometer against the dry roof of baby's axilla, baby arm was held close to body in order to keep thermometer in place temperature was taken after 1,5 minutes and after 1 hour of birth.

\section{RESULTS}

120 women were selected for the study. These women were divided into equal halves. Mean age of these women was as $26.7 \pm 5.0$ years. In group "A" the mean age of the patients was $27.5 \pm 5.0$ years compared with second half which was 25.8 \pm 4.7 years. In group "B" patients had younger 
patients as compared to in group "A". Majority of patients in group "A" and group" B" was 58\% $(n=29)$ vs $50 \%(n=25)$ were between age group of 25 to 31 years as shown in Table-l.

\begin{tabular}{|l|c|c|c|c|}
\hline $\begin{array}{c}\text { Age group } \\
\text { (years) }\end{array}$ & \multicolumn{2}{|c|}{$\begin{array}{c}\text { Conventional } \\
\text { Method }\end{array}$} & \multicolumn{2}{c|}{$\begin{array}{c}\text { Skin to skin } \\
\text { mother contact }\end{array}$} \\
\hline & $\mathbf{n = 6 0}$ & $\mathbf{( \% )}$ & $\mathbf{n = 6 0}$ & $\mathbf{( \% )}$ \\
\hline $18-24$ & 17 & 28.0 & 22 & 36.0 \\
\hline $25-31$ & 29 & 48.0 & 25 & 41.0 \\
\hline$\geq 32$ & 14 & 23.0 & 13 & 21.0 \\
\hline Mean \pm S.D & $27.5 \pm 5.2$ & $25.8 \pm 4.7$ \\
\hline
\end{tabular}

In group "B" the gravida was found as between 1 to 6 children in $64 \%(n=32)$ of patients compared with group "A" $60 \%(n=30)$ of patients in Table-II. In group "B" the parity was found as between 1 to 4 children in $52 \%(n=26)$ of patients compared with group "A" $52 \%(n=26)$ of patients in Table-III.

\begin{tabular}{|l|c|c|c|c|}
\hline Gravida & \multicolumn{2}{|c|}{$\begin{array}{c}\text { Conventional } \\
\text { Method }\end{array}$} & \multicolumn{2}{c|}{$\begin{array}{c}\text { Skin to skin mother } \\
\text { contact }\end{array}$} \\
\cline { 2 - 6 } & $\mathbf{n = 6 0}$ & $\mathbf{( \% )}$ & $\mathbf{n = 6 0}$ & $\mathbf{( \% )}$ \\
\hline PG & 20 & 33.0 & 16 & 26.0 \\
\hline $1-6$ & 30 & 50.0 & 32 & 53.0 \\
\hline $7-10$ & 10 & 16.0 & 12 & 20.0 \\
\hline \multicolumn{2}{r|}{ Table-II. Distribution of gravida by groups } \\
\hline \multicolumn{2}{r}{} \\
\hline
\end{tabular}

\begin{tabular}{|l|c|c|c|c|}
\hline Parity & \multicolumn{2}{|c|}{$\begin{array}{c}\text { Conventional } \\
\text { Method }\end{array}$} & \multicolumn{2}{c|}{$\begin{array}{c}\text { Skin to skin mother } \\
\text { contact }\end{array}$} \\
\hline & $\mathbf{n = 6 0}$ & $\mathbf{( \% )}$ & $\mathbf{n = 6 0}$ & $\mathbf{( \% )}$ \\
\hline 0 & 16 & 26.0 & 17 & 28.0 \\
\hline $1-4$ & 30 & 50.0 & 27 & 45.0 \\
\hline $5-8$ & 14 & 23.0 & 16 & 26.0 \\
\hline & Table-III. Distribution of parity by groups \\
\hline
\end{tabular}

The overall mean hospital stay was as $6.6 \pm 1.6$ hours. In group "A" the mean hospital stay was $6.5 \pm 1.5$ hours compared with in group "B" was $6.7 \pm 1.8$ hours.

Personal health response like was found in $76 \%$ $(\mathrm{n}=38)$ patients in group "A" compared with in group " $B$ " $86 \%(n=43)$ patients as shown in Table-IV. Mother response like was found in $76 \%$ $(\mathrm{n}=38)$ patients in group "A" compared with in group B 76\% $(n=38)$ patients as shown in Table-V.

\begin{tabular}{|l|c|c|c|c|}
\hline $\begin{array}{l}\text { Health personal } \\
\text { response }\end{array}$ & \multicolumn{2}{|c|}{$\begin{array}{c}\text { Conventional } \\
\text { Method }\end{array}$} & \multicolumn{2}{c|}{$\begin{array}{c}\text { Skin to skin } \\
\text { mother contact }\end{array}$} \\
\cline { 2 - 6 } & $\mathbf{n = 6 0}$ & $\mathbf{( \% )}$ & $\mathbf{n = 5 0}$ & $\mathbf{( \% )}$ \\
\hline Like & 38 & 63.0 & 43 & 71.0 \\
\hline Dislike & 6 & 10.0 & 7 & 11.0 \\
\hline No response & 16 & 26.0 & 10 & 16.0 \\
\hline Table-IV. Distribution of health personal response by \\
groups
\end{tabular}

\begin{tabular}{|l|c|c|c|c|}
\hline $\begin{array}{l}\text { Health personal } \\
\text { response }\end{array}$ & \multicolumn{2}{|c|}{$\begin{array}{c}\text { Conventional } \\
\text { Method }\end{array}$} & \multicolumn{2}{c|}{$\begin{array}{c}\text { Skin to skin } \\
\text { mother contact }\end{array}$} \\
\hline $\mathbf{n = 5 0}$ & $\mathbf{( \% )}$ & $\mathbf{n = 5 0}$ & $\mathbf{( \% )}$ \\
\hline Like & 38 & 63.0 & 41 & 68.0 \\
\hline Dislike & 6 & 10.0 & 7 & 11.0 \\
\hline No response & 16 & 26.6 & 12 & 20.0 \\
\hline Table-V. Distribution of mother response by groups
\end{tabular}

Statistical significant mean difference in temperature of after 1 hours was observed $(p=0.001)$ between group "A" and group "B", no significant mean difference in temperature ${ }^{\circ} \mathrm{F}$ after 1 and after 5 minutes were observed $(p>0.05)$ compared group "A" and group "B" as shown in Table-VI.

\begin{tabular}{|l|c|c|c|c|}
\hline & \multicolumn{2}{|c|}{$\begin{array}{c}\text { Conventional } \\
\text { Method }\end{array}$} & $\begin{array}{c}\text { Skin to skin mother } \\
\text { contact }\end{array}$ \\
\hline $\begin{array}{l}\text { Temp- } \\
\text { erature }\end{array}$ & $\begin{array}{c}\text { Mean } \\
\pm \text { S.D } \\
\mathbf{n = 5 0}\end{array}$ & $\begin{array}{c}\text { Mean } \\
\pm \text { S.D } \\
\mathbf{n = 5 0}\end{array}$ & $\begin{array}{c}\text { Mean } \\
\text { difference }\end{array}$ & p-value \\
\hline $\begin{array}{l}\text { Recoding } \\
\text { after 1 min }\end{array}$ & $\begin{array}{c}97.3 \pm \\
1.1\end{array}$ & $\begin{array}{c}97.2 \pm \\
1.0\end{array}$ & 0.124 & 0.576 \\
\hline $\begin{array}{l}\text { Recoding } \\
\text { after 5 } \\
\text { mins }\end{array}$ & $\begin{array}{c}97.5 \pm \\
1.0\end{array}$ & $\begin{array}{c}97.7 \pm \\
0.9\end{array}$ & -0.230 & 0.258 \\
\hline $\begin{array}{l}\text { Recoding } \\
\text { after 1 } \\
\text { hour }\end{array}$ & $\begin{array}{c}97.7 \pm \\
0.8\end{array}$ & $\begin{array}{c}98.2 \pm \\
0.6\end{array}$ & -0.516 & 0.001 \\
\hline $\begin{array}{l}\text { Table-IV. Comparison of temperature at different point } \\
\text { in time by groups }\end{array}$ \\
\hline
\end{tabular}

\section{DISCUSSION}

This study was conducted to obtain views of Pakistani health care providers. Although the research showed the positive results regarding skin to skin contact between mother and the new born (SCC) while, this practice not used routinely in developing country including in Pakistan. No study has explained the reasons.

There are many recently published studies ${ }^{9}$ 
showed the great benefits of skin-to-skin contact soon after delivery including secretion of oxytocin in mothers' blood which leads to faster placenta removal and reduction of uterine bleeding. ${ }^{10}$ Other benefits for neonates are stabilization of the newborn's body temperature ${ }^{11,12}$ and respiration ${ }^{13}$, heart rate regulation and oxygen saturation consequent to (SSC)..$^{14}$ This showed majority of participants addressed all these benefits for mother and newborn.

Skin to Skin Contact (SSC) is the natural process to start breast feeding soon after delivery. It is novel, easy, readily available, easily reproducible technique which helps mothers initiate breast feeding in a natural way. ${ }^{15}$ As it has been developed in 1987 for the first time, in Sweden ${ }^{11,14}$, the human normal newborn like any mammal's neonate, has the inborn ability to crawl on the mother's abdomen to find her mother's breast for breastfeeding immediately after birth. ${ }^{13}$

Soon after the delivery, a baby is usually active then goes in stage of deep sleep. When requires rest and recovery which is perfect stage for latching on to the breast. ${ }^{16}$ The first latch-on has critical importance and has a positive impact on long-term lactation success. Its most important benefits are significant reduction of malnutrition, mortality and morbidity among the children. Early initiation in the first hour of the birth can prevent $22 \%$ of neonatal death in developing countries. ${ }^{13}$

\section{MOTHER RESPONSE REGARDING SKIN TO SKIN CONTACT}

Ten women were selected for randomized trial done by Widstrom et al (1990) which showed immediate contact of the breast within 30 minutes of delivery increase bonding of mother and new born. 32 women whose new born when come in contact with mother's breast and start feeding they left their babies in the day care centers for limited time period and they were more worried about their babies than other half of the women who were permit to skin to skin contact without breast feeding. ${ }^{17}$

In Karolinska Institutet, Stockholm, Sweden;
Hospital on research carried out regarding axillary temperature at form half our hour to two hours after delivery. Babies who are in women's arm and nursery groups, showed significant difference in temperature (P-Value 0.0001). Same results showed in the studies of ANOVA and FISHER's. ${ }^{18}$

With passage of time raised temperature is noted $\left(\mathrm{DF}=6, \mathrm{~F}\right.$-value $=127.5, \mathrm{p}_{-}$0.0001), and this rise in temperature differs significantly with both groups. $(\mathrm{DF}=12, \mathrm{~F}$-value $=5.57, \mathrm{p}=0.0001$ )

Average temperature of thigh at from thirty to one hundred twenty minutes after delivery in skin to skin contact in mother's arm and nursery group while the study done by ANOVA, their result showed significant difference in temperature (DF $=2$, F-value $=40.75, p \_0.0001$ ) .

Similar results were found in our study which was done in 120 women were suitable in the criteria for this study. In this study criteria of the age were compared and the result showed mean age of women were $27.5 \pm 5.2$ years as compared to second half of women in which result showed $25.8 \pm 4.7$ years.

\section{CONCLUSION}

In our setup due to over burden of work, this study may help in developing new practices for maintaining body temperature of new born. We can save many babies from hypothermia by providing skin to skin contact of mother and newborn, because it is easy, highly effective, time saving practice. The usual practice of our ward is the conventional technique in which baby is delivered, cord is cut immediately and newborn is handed over to health staff (doctor/ nurse), who took the baby, to infant warmer and assessed for further resuscitation. if such practice continue here with heavy work load and limited availability of warmers then we could not achieve the millennium development goal (MDG) for that is to decrease neonatal mortality.

From my study I have concluded that skin to skin contact reduces hypothermia, so it should be 
encouraged and continue. Skin to skin contact is easy, cheap and helps in bonding of mother and baby.

Copyright(C) 15 Feb, 2017.

\section{REFERENCES}

1. CJ, Laakso T, Shibuya K, Hill K, Lopez AD: Can we achieve Millennium Development Goal 4? New analysis of country trends and forecasts of under-5 mortality to 2015. Lancet2007, 370:1040-1054.

2. Raja ratnam JK, Marcus JR, Flaxman $A D$, Wang $H$, Levin-Rector A, Dwyer L, Costa M, Lopez AD, Murray $\mathrm{CJ}$ : Neonatal, postneonatal, childhood, and under5 mortality for 187 countries, 1970-2010: a systematic analysis of progress towards Millennium Development Goal 4. Lancet 2010, 375:1988-2008.

3. Knobel R, Holditch-Davis D: Thermoregulation and heat loss prevention after birth and during neonatal intensive-care unit stabilization of extremely lowbirth weight infants. J Obstet Gynecol Neonatal Nurs2007, 36:280-287.

4. Mullany LC, Katz J, Khatry SK, Lecler q SC, Darmstadt GL, Tielsch JM: Incidence and seasonality of hypothermia among new borns in southern Nepal. ArchPediatrAdolescMed2010, 164:71-77.

5. Righard L, Alade MO. Effect of delivery room routines on success of first breast-feed. Lancet 1990; 336:1105-7.

6. Albert's JR. Learning as adaptation of the infant. Acta Paediatrica Supplement 1994; 397:77-85.

7. UNICEF: Levels \& Trends in Child Mortality, Estimates Developed by the UNInter-agency Group for Child Mortality Estimation, Report 2010.

8. Black RE, Cousens S, Johnson HL, Lawn JE, Rudan I, Bassani DG, JhaP, Camp bell H, Walker CF, Cibulskis R, Eisele T, Li, L, Mather, C: Global, regional, and national causes of child mortality in2008:asystematic analysis. Lancet2010, 375:1969-1987.

9. Marshall H. Klaus, M.D., Richard Jerauld, B.S., Nancy C. Kreger, B.S., Willie McAlpine, B.S., Meredith Steffa, B.S., and John H. Kennell, M.D. Maternal Attachment
- Importance of the First Post-Partum Days. N Engl J Med 1972; 286:460-463March 2, 1972 DOI: 10.1056/ NEJM197203022860904.

10. Mother and Infant: Early Emotional Ties. PEDIATRICS 1998; 102(5). Downloaded from www.pediatrics.org by on March 8, 2007.

11. Bystrova K, Widstrom AM, Matthiesen AS, et al. Skin-toskin contact may reduce negative consequences of "the stress of being born": a study on temperature in newborn infants, subjected to different ward routines in St. Petersburg. Acta Paediatr 2003; 92:320-6.

12. Ransjo-Arvidson $A B$, Matthiesen AS, Lilja $G$, et al. Maternal analgesia during labor disturbs newborn behavior: effects on breastfeeding, temperature, and crying. Birth 2001; 28:5-12.

13. Camacho LL, Rojas EP, et al. Kangaroo mother method: randomized controlled trial of an alternative method of care for stabilized low-birth weight infants. Lancet. 1994; 344:782-785.

14. Yuki Takahashi, Koji Tamakoshi, Miyoko Matsushima, Tsutomu Kawabe. Comparison of salivary cortisol, heart rate, and oxygen saturation between early skin-to-skin contact with different initiation and duration times in healthy, full-term infants. Early Human Development 87 (2011) 151-157.

15. Bhagat K. Breast Crawl: The natural method of initiation of breastfeeding. Video presentations / International Journal of Gynecology \& Obstetrics 107S2 (2009) S397-S412.

16. Karl, D. Using principles of newborn state organization to facilitate breastfeeding. MCN. The American Journal of Maternal Child Nursing. 2004; 29, 292-298.

17. Widstrom AM, Wahlberg V, Mathieson AS, Eneroth $P$, Uvnas-Moberg K, Winberg J (1990) Short-term effects of early suckling and touch of the nipple on maternal behavior. Early Human Development. 21:153-163.

18. Bystrova, K., et al. "Skin $\square$ to $\square$ skin contact may reduce negative consequences of "the stress of being born": a study on temperature in newborn infants, subjected to different ward routines in St. Petersburg." Acta Paediatrica 92.3 (2003): 320-326.APA 


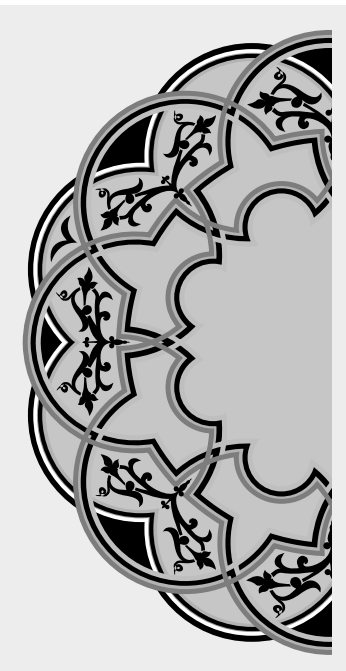

\title{
"Intelligence without ambition is a bird without wings "
}

\author{
Unknown
}

\section{AUTHORSHIP AND CONTRIBUTION DECLARATION}

\begin{tabular}{|c|c|c|c|}
\hline Sr. \# & Author-s Full Name & Contribution to the paper & Author $=\mathbf{s}$ Signature \\
\hline 1 & Dr. Sadia Irum & $\begin{array}{l}\text { Literature search proforma } \\
\text { formation, data collection and } \\
\text { data analysis. }\end{array}$ & \\
\hline 2 & Dr. Nigar Jabeen & Data collection, Literature search & \\
\hline 3 & Dr. Raheela Baloch & Study concept literature search & \\
\hline 4 & Ms. Kiran Mawani & Data collection and data analysis & \\
\hline
\end{tabular}

